\title{
Pelatihan Pengoperasian Media Pembelajaran bagi Guru untuk Meningkatkan Profesionalitas GURU
}

\author{
${ }^{1}$ Carlina Sukma Ayu Kurniawan, ${ }^{2}$ Deni Ainur Rokhim, ${ }^{3}$ Imamul Huda Al Siddiq \\ ${ }^{1}$ Administrasi Pendidikan Universitas Negeri Malang, ${ }^{2}$ Pendidikan Kimia Universitas Negeri \\ Malang, ${ }^{2}$ Kimia, SMAN 3 Sidoarjo, ${ }^{3}$ Pendidikan Guru dan Sekolah Dasar Universitas Negeri Malang \\ email: ${ }^{1}$ sukmacarlina6@gmail.com, ${ }^{2}$ deniainurrokhim@gmail.com, ${ }^{3}$ Imamul.huda.fis@um.ac.id
}

\begin{abstract}
The training activities were carried out at SMPN 1 Krembung which aimed to improve the professionalism of teachers in the operation of electronic-based learning media. This dedication is a descriptive study with a quantitative approach. Data collection techniques used in the form of lectures, discussions, training, and documentation. The data obtained was analyzed descriptively quantitatively. The activities carried out are: (1) providing understanding for teachers about the importance of utilizing developing technology as a learning medium, and (2) conducting simulations of making electronic-based learning media ranging from how to create to the operation of electronic-based learning media. This activity was attended by twenty teachers from SMP Negeri 1 Krembung. Seventeen teachers understood the benefits and ways of using electronic learning media as well.

Keywords: Training, learning media, electronics, teacher professionalism, Junior High School 1 Krembung
\end{abstract}

\begin{abstract}
Abstrak. Kegiatan pelatihan dilakukan di SMPN 1 Krembung yang bertujuan untuk meningkatkan kemampuan profesionalisme guru dalam pengoprasian media pembelajaran berbasis elektronik. Pengabdian ini merupakan penelitian deskriptif dengan pendekatan kuantitatif. Teknik pengumpulan data yang digunakan dalam bentuk ceramah, diskusi, pelatihan, dan dokumentasi. Data yang telah diperoleh dianalisis secara deskriptif kuantitatif. Adapun kegaiatn yang dilakukan adalah: (1) memberikan pemahaman bagi guru mengenai pentingnya memanfaatkan teknologi yang berkembang sebagai media pembelajaran, dan (2) melakukan simulasi pembuatan media pembelajaran berbasis elektronik mulai dari cara mebuatan hingga pengoprasian media pembelajaran berbasis elektronik. Kegiatan ini diikuti oleh dua puluh guru SMP Negeri 1 Krembung. Sejumlah tujuh belas guru memahami manfaat dan cara menggunakan media pembelajaran media pembelajaran berbasis elektronik dengan baik.
\end{abstract}

Kata Kunci: Pelatihan, media pembelajaran elektronik, profesionalisme guru, SMP Negeri 1 Krembung

\section{Pendahuluan}

Semakin berkembangnya zaman, akan berdampak juga tehadap perkembangan teknologi dan informasi. Perkembangan teknologi dan informasi mempengaruhi perkembangan ilmu yang ada, terutama dalam dunia pendidikan. Hal ini dipengaruhi oleh mekanisme proses belajar mengajar yang menggunakan teknologi. Dengan adanya perubahan mekanisme pembelajaran, maka profesionalisme guru harus menyesuaikan dengan menggunakan teknologi dalam proses belajar. Hal ini diperjelas dalam Undang-Undang Republik Indonesia Nomor 14 Tahun 2005 Tentang Guru Dan Dosen (2005) tentang guru dan dosen bahwa kompetensi yang harus dimiliki yakni kompetensi pedagogik, kepribadian, sosial, dan profesional. Keempat 
kompetensi tersebut harus melekat pada diri guru dalam melaksanakan tugasnya di sekolah. Kompetensi profesional guru dalam Peraturan Pemerintah Republik Indonesia Nomor 19 Tahun 2005, (2005) yakni kemampuan penguasaan materi pembelajaran secara luas dan mendalam yang memungkinkannya dalam membimbing peserta didik memenuhi standar kompeteni yang ditetapkan dalam Standar Nasional Pendidikan.

Pemaparan mengenai profesinalitas guru yang telah dipaparkan pada Undang-Undang dan Peraturan Pemerintah merupakan hal yang wajib dimiliki oleh setiap guru yang ada di Indonesia. Pada Dasarnya keberhasilan pendidikan dipengaruhi oleh beberapa faktor yang saling berkaitan satu sama lain yakni guru, materi pembelajaran, dan peserta didik (Deda, 2019).

Dari ketiga faktor dalam pendidikan tersebut guru merupakan faktor yang paling dominan dalam kegiatan belajar mengajar yang terlaksana di sekolah, oleh karena itu profesionalisme guru sangatlah dibutuhkan. Pada era globalisasi ini profesinalitas guru sangatlah diperhatikan, karena gutu tidak hanya menyampaikan informasi ilmu pengetahuan melainkan guru harus dapat memanfaatkan perkembangan teknologi dalam menyampaikna ilmu pengetahuan, (Anggrasari, 2017).

Adanya perkembangan teknologi informasi akan berdampak pada tiga hal yakni pola hubungan guru dan peserta didik, teknologi instruksional, dan sistem pendidikan secara keseluruhan. Oleh karena itu, guru harus mampu meningkatkan kompetensinya dalam penguasaan teknologi yakni mengenai pengembangan media pembelajaran berbasis ICT (Information and Communication Technology) (Ceha, 2016). Pengembangan media berbasis ICT ini menjadi hal penting yang harus dikuasai oleh guru, karena dengan guru yng telah menguasai perkembangan teknologi nantinya diharapkan mampu memodifikasi pembelajaran agar kualitas pembelajaran yang diharapkan dan dihasilkan sesuai dengan perkembangan teknologi saat ini. Hadirnya ICT dalam dunia mendidikan menjadikan adanya perubahan anggapan mengenai belajar bahwa belajar tidak hanya dari kelas, belajar tidak hanya melalui buku, dan belajar dapat dilakukan dimana saja dan kapan saja. Dalam memenuhi tantangan tersebut, guru dituntut untuk meningkatkan pengetahuan dan kemampuan dalam bidang teknologi, teruama pembuatan media pembelajaran yang berbasis elearning (Fajar, 2017).

Namun, kenyataannya meskipun teknologi berkembang pesat akan tetapi guru-guru di Indonesia masih belum semua mampu untuk mengikuti perkembangan teknologi. Hal ini menurut Chaeruman (2019) disebabkan oleh 1) adanya penolakan untuk melakukan perubahan (resistancy to change) khuusnya dari kebijakan sekolah dan guru, 2) kesiapan Sumber Daya Manusia (SDM) dalma menghadapi perubahan, 3) ketersediaan fasilitas TIK, 4) ketersediaan bahan belajar dengan berbagai sumber, dan keberangsungan (sustainability). Pada penelitian yang dilakukan oleh Sumintono et al., (2012) bahwa 21\% dari guru yang telah menggunakan pembelajaran TIK ataupun berbasis tekonologi mengalami kesulitas pada pemanfaatan perangkat proyeksi (LCD) yang disebabkan oleh kemampuan dalam berbahasa Inggris guru. Kesulitan yang dialami oleh guru tersebut menurut Rivalina (2014) disebabkan oleh 1) guru yang mempunyai jam mengajar yang sangat padat pada setiap harinya, 2) pelatihan dibidang teknologi yang belum dapat menjangkau semua guru yang ada di Indonesia, 3) jarak tempat tinggal guru 
dan sekolah yang jauh, dan 4) belum semua guru memiliki fasilitas laptop. Untuk mengatasi kesulitan yang dihadapi oleh guru, tidak selalu bergantung kepada pemerintah untuk memberi pelatihan, namun dari kalangan mahasiswa juga dapat membantu permasalahan yang dihadapi oleh guru dengan menerapkan poin ke tiga dari Tri Dharma Perguruan tinggi yakni pengabdian kepada masyarakat. Mahasiswa yang diharapkan mampu tumbuh, berkembang, dan menjadi harapan masa depan bangsa. Peran mahasiswa disini dibutuhkan dalam memberikan pengetahuan baru kepada guru mengenai perkembangan teknologi dalam pembelajaran, yang nantinya membangun motivasi guru untuk lebih meningkatkan kemampuannya dalam mengajar dengan mengikuti perkembangan teknologi masa kini. Kegiatan pelatihan yang diadakan mahasiswa untuk meningkatkan pengetahuan dan profesionalisme juga dilakukan oleh Somantri et al., (2017) mengenai peningkatan kemampuan guru dalam membuat E-Learning sebagai media pembelajaran berbasis teknologi informasi yang dilakukan di SMA Negeri 1 Subah, yang memiliki hasil pengetahuan guru bertambah mengenai media pembelajaran berbasis e-learning, hal ini dapat diketahui dari pre-test sebelum pelatihan di mulai dan post-test memiliki kenaikan nilai secara signifikan. Rosy et al., (2018) juga melaksanakan pelatihan media pembelajaran berbasis e-learning untuk guru SMK program keahlian administrasi perkantoran di Kabupaten Jombang Jwa Timur dengan hasil yang sangat positif, yang dapat dilihat dari antusiasme guru mengikuti kegiatan pelatihan, dan hasil dari pelatihan yang telah dilakukan. Hasil penelitian oleh Sari et al., (2019) mengenai pelatihan membuat media pembelajaran interaktif berbasis teknologi informasi memiliki hasil yang memuaskan, yang dapat dilihat melalui antusiasme guru dalam mempratekkan apa yang telah dajarkan oleh tim pengabdian, dan dapat membuat media pembelajaran interaktif secara mandiri. Dari kegiatan pelatihan yang dilakukan tersebut, dapat diketahui bahwa dengan adanya kegiatan pelatihan mengenai media pembelajaran berbasis teknologi dalam rangka meningkatkan pengetahuan dan profesionalisme guru merupakan hal yang sangat membantu. Pengetahuan dan profesionalisme guru semakin berkembang dan dapat mengimbangi perkembangan teknologi, sehingga meminimalisir guru yang buta akan teknologi. Dalam mencapai tujuan tersbut, tim pengabdian melaksankaan pelatihan di SMPN 1 Krembung.

\section{Metode}

Kegiatan pelatihan yang dilaksanakan meliputi: (1) sosialisasi program dan kerja sama ke sekolah, (2) pelaksanaan pelatihan dengan guru, (3) evaluasi kegiatan pelatihan. Sosialisasi dilakukan dengan melakukan kunjungan ke sekolah untuk menyampaikan maksud dan tujuan pelatihan diadakan kepada guru. Kegiatan sosialisasi ini diharapkan dapat menjalin kerja sama antara pihak Universitas Negeri Malang dengan sekolah mitra, yakni SMP Negeri 1 Krembung, sehingga pelatihan yang akan dijalankan mendapat formalitas dan persetujuan antara kedua belah pihak.

Pelatihan meliputi kegiatan persiapan dan pelaksanaan. Persiapan program meliputi: (1) menentukan jadwal pelatihan, (2) menyiapkan materi yang akan disampaikan, (3) menyiapkan peralatan yang digunakan untuk pelatihan, (4) menggandakan materi dalam bentuk hard file. Penyusunan materi dilakukan oleh tim pengabdian, yang dilakukan dengan membagi tugas pada setiap anggota tim dengan acuan konsep yang teah dibuat sebelumnya. Pelaksanaan kegiatan pelatihan 
meliputi: (1) penyampaian materi kepada guru, (2) mendampingi guru dalam mempratekkan meteri yang telah disampaikan, (3) proses tanya jawab antara guru dengan tim pengabdian. Tanya jawab dilakukan bertujuan untuk mengetahui tingkat kepahaman guru mengenai meteri yang telah diberikan, dan sebagai bentuk antusiasme guru dalam mengikuti pelatihan.

Evaluasi kegiatan pelatihan yang dilaksanakan dilakukan secara bersamaan saat kegiatan pelatihan berlangsung, dengan melihat hasil dari media yang telah dikerjakan oleh guru. Hal tersebut menjadi tolak ukur pemahaman guru dengan materi yang disampaikan saat pelatihan.

Data yang diperoleh dari penelitian ini adalah data kualitatif dan kuantitatif Data kualitatif diperoleh dari perspektif guru dalam mengisi pertanyaan terbuka, sedangkan data kuantitatif diperoleh dari pendapat guru dalam menentukan kriteria jawaban. Teknik pengumpulan data yang digunakan adalah penyebaran angket dan wawancara. Sampel dalam penelitian terdiri dari 20 guru SMPN 1 Krembung, Sidoarjo, Jawa Timur.

\section{Hasil dan Pembahasan}

Kegiatan pelatihan pengoprasian media pembelajaran berbasis elektronik yang bertujuan untuk meningkatkan profesionalisme mengajar guru dengan menggunakan teknologi ini dilaksanakan di SMP Negeri 1 Krembung, Desa Mojoruntut, Kecmatan Krembung, Kabupaten Sidoarjo, pada hari Senin 24 Juni 2019 dan Selasa 25 Juni 2019. Sebelum membahas mengenai kegiatan dan hasil yang dipaparkan dalam penelitian ini, tim pengabdian akan mengemukakan hasil pelatihan pelatihan yang diadakan di tempat yang berbeda sebagai data penelitian terdahulu dan penguat dari hasil pelatihan yang akan dipaparkan.
Pelatihan media pembelajaran berbasis ICT pada guru di lembaga pendidikan Non-Formal TPQ yang dilakukan oleh Muslih (2016) memiliki hasil bahwa dengan diadakannya pelatihan tersebut, guru menjadi mudah dalam menyampaikan materi pembelajaran, karena materi yang akan disampaikan telah disiapkan sebelumnya, sehinga waktu untuk proses penyampaian materi menjadi efektif dan efisien. Pelatihan serupa juga dilakukan oleh Irmade \& Widjanarko (2019) yang dilakukan di TK Rumah Pelangi Colomandu Karanganyar. Hasil penelitian tersebut mengungkapkan guru antusias dalam mengikuti pelatihan karena hal yang diajarkan merupakan pengetahuan baru dan menarik, kemudian pelatihan pembuatan media berbasis ICT yang dilaksanakan dapat meningkatkan kemampuan dan keterampilan semua guru, dibuktikan dengan kemampuan sembilan guru yang dapat membuat media pembelajaran berbasis ICT. Trisisca \& Sulistyo (2017) melakukan pelatihan serupa yang dilaksanakan di Kecamatan Bantur. Hasil pelatihan tersebut $85 \%$ guru yang mengikuti pelatihan dapat memahami penggunaan internet untuk mengunggah metode pembelajaran yang inovatif.

Dari paparan penelitian terdahulu tersebut, nantinya akan dapat dibadingkan dengan kegiatan pelatihan yang dilaksanakan di SMP Negeri 1 Krembung. Kegiatan pelatihan yang dilakukan oleh tim pengabdian berjalan secara tertib, baik, dan lancara dan diikuti oleh dua puluh guru. adapun hasil yang diperoleh dapat ditunjukkan berdasarkab pelaksanaan yang dilakukan dengan pembahasan sebagai berikut. 


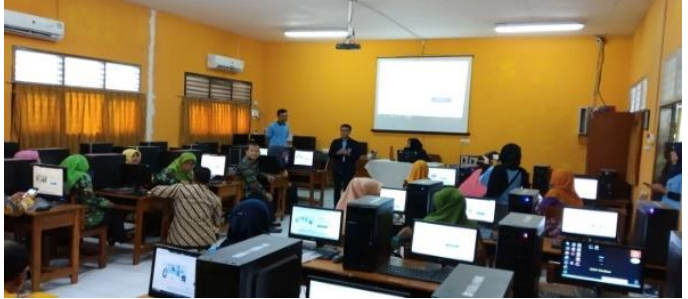

Gambar 1

Pada kegiatan hari pertama yang dapat dilihat pada gambar 1, tim pengabdian memulai dengan melakukan perkenalan dan menyampaikan maksud dari tujuan diadakannya pelatihan media pembelajaran berbasis elektronik dalam meningkatkan profesionalisme guru dalam mengajar. Penyampaian materi yang dilakukan oleh tim pengabdian yakni melalui media power point. Selain menyampaikan materi melalui media power point, tim pengabdian menggunakan metode diskusi mengenai materi yang dijelaskan yakni pertama pentingnya media pembelajaran berbasis elektronik. Kedua, pentingnya guru mengikuti perkembangan teknologi yang berguna dalam dunia pendidikan, dan ketiga memberikan pengetahuan dasar mengenai pentingnya menggunakan media pembelajaran dengan memanfaatkan teknologi saat ini. Penjelasan ketiga materi diatas, dilandasi oleh tim pengabdian dengan alasan kemampuan guru dan profesionalisme guru semakin dituntut dalam melaksanakan pembelajaran pada zaman sekarang. Agar guru yang mengikuti pelatihan memiliki pandangan yang lebih luas mengenai penggunaan media pembelajaran. Tidak lupa, tim pengabdian juga memberikan contoh mengenai media pembelajaran berbasis elektronik kepada guru, yakni media pembelajaran powton dan schology. Hal ini bertujuan agar guru dapat menjadikan contoh tersebut sebagai reverensi dalam membuat medua pembelajaran berbasis elektronik tersebut, sebelum memasuki praktik dalam membuat dan megoprasikan media pembelajaran berbasis elektronik pada hari kedua pelatihan. Tim pengabdian memilih powton dan schology karena kedua web tersebut sangat mumpuni untuk kegiatan pembelajaran E-learning, karena memberikan akses pada guru dan siswa untuk presensi, pengumpulan tugas, latihan soal, dan media sumber belajar yang bisa diakses kapanpun dan dimanapun serta juga memberikan akses pada orang tua untuk memantau perkembangan belajar siswa di sekolah. Dengan penggunaan media pembelajaran elektronik melalui powton dan schology, diharapkan kemampuan guru menjadi lebih baik dan dapat mengikuti perkembangan teknologi informasi, yang nantinya secara tidak langsung berpengaru profesionalisme yang dimiliki oleh guru. Kegaiatan pada hari pertama dapat dikatakan terlaksana dengan baik yang dibuktikan dengan banyaknya pertanyaan yang dilontarkan oleh guru saat diskusi sebagai bentuk antusias saat mengikuti kegiatan pelatihan.

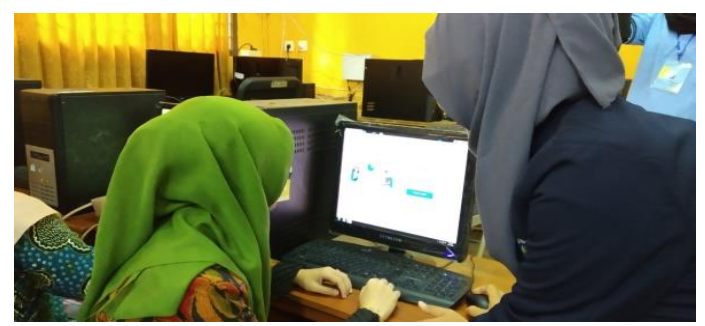

\section{Gambar 2}

Pada Gambar 2 menjelaskan kegiatan pelatihan pada hari ke dua yang merupakan puncak dari dilaksnakannya pelatihan media pembelajaran berbasis elektronik guna meningkatkan profesionalisme guru, karena lebih banyak praktek secara langsung dalam pembuatan dan pengoprasian media pembelajaran berbasis elektronik. Tim pengabdian membebaskan peserta pelatihan dalam membuat tema atau meteri pembelajaran dengan menggunakan web powton dan schology. Namun, sebelum guru 
membuat materi pada website, tim pegabdian mengulas kembali cara mengoprasikan website secara singkat. Pada saat guru membuat materi, tim pengembang mendampingi guru untuk membantu guru saat mengalami kendala saat membuat materi.

Berdasarkan pengamatan yang dilakukan saat pelaksanaan pelatihan berlangsung, maka kegiatan pelatihan ini memberikan manfaat yang besar untuk meningkatkan kemampuan guru dalam membuat media pembelajaran berbasis elektronik. Kegiatan ini dapat dikatan berhasil berdasarkan antusias para peserta pelatihan dalam mengajukan pertanyaan kepada tim yang mendampingi guru saat mereka membuat media pembelajaran. Selain dari pengamatan, tim pengabdian juga mengukur pemahaman guru dan manfaat mengenai penggunaan media pembelajaran berbasis eletronik menggunakan angket.

Angket yang telah diisini oleh guru yang mebgikuti kegiatan pelatihan menunjukkan hasil bahwa, ada 11 guru yang miliki nilai tinggi. Nilai tersebut menunjukkan bahwa guru memahami mengenai materi yang disampaikan saat pelatihan, dan manfaat penggunaan media pembelajaran berbasis elektronik. Terdapat 6 guru yang memiliki nilai dengan kategori sedang, karena dalam angekt menunjukkan terdapat beberapa poin yang belum dipahami oleh guru mngenai pengoprasian media pembelajaran elektronik, dan 3 guru yang memiliki nilai rendah menunjukkan bahwa guru belum memahami secara utuh menegnai pembuatan materi dan pengoprasian media pembelajaran berbasis elektronik. Hasil angket secara ringkas dapat dilihat melalui Tabel 1.
Tabel 1. Hasil Angket Pelatihan

\begin{tabular}{llr}
\hline No & Kategori & Jumlah \\
\hline 1 & Tinggi & 11 \\
2 & Sedang & 6 \\
3 & Rendah & 3 \\
\hline \multicolumn{3}{c}{ Selain hasil angket yang } \\
didapatkan, tim pengabdian juga \\
meminta pendapat akan kegiatan \\
pelatihan yang telah dilaksanakan \\
selama dua hari tersebut. Perwakilan dari \\
guru mengungkapkan bahwa pelatihan \\
yang telah diadakan sangat \\
menyenangkan, dan r banyak \\
menginspirasi guru dalam membuat \\
media pembelajaran. Kemampuan guru \\
juga bertambah sehingga, mereka dapat \\
membuat pembelajaran di kelas lebih \\
menyenangkan dengan menggunakan \\
media pembelajaran elektronik.
\end{tabular}

\section{Kesimpulan dan Saran}

Kegiatan pelatihan mengenai pengoprasian mendia pembelajaran berbasis elektronik untuk meningkatkan profesionalisme guru dalam melaksankaan pembelajaran bertujuan untuk (1) memberikan pemahaman bagi guru mengenai pentingnya memanfaatkan teknologi yang berkembang sebagai media pembelajaran, dan (2) melakukan simulasi pembuatan media pembelajaran berbasis elektronik mulai dari cara mebuatan hingga pengoprasian media pembelajaran berbasis elektronik.

Hasil dari kegiatan ini yaknik sejumlah tujuh belas guru memahami manfaat dan cara menggunakan media pembelajaran media pembelajaran berbasis elektronik dengan baik dengan mendapat nilai dengan kategori tinggi dan sedang. Sedangkan ada tiga guru yang memiliki nilai rendah.

Untuk mencapai tujuan guru yang profesionalisme guru, kegiatan pelatihan seharusnya dilakukan secara kontinyu dari berbagai pihak. Hal ini bertujuan untuk meningkatkan pengetahuan dan kemampuan yang 
dimiliki guru dan sekaligus dapat memantau perkembangan guru dalam proses pembelajaran.

\section{DAFTAR PUSTAKA}

Anggrasari, L. A. (2017). Meningkatkan Profesionalisme Guru Sekolah Dasar Melalui Pengembangkan Media Pembelajaran Online Berbasis Edmodo. .. ISSN, 5.

Ceha, R., Prasetyaningsih, E., \& Bachtiar, I. (2016). Peningkatan Kemampuan Guru dalam Pemanfaatan Teknologi Informasi pada Kegiatan Pembelajaran. ETHOS: Jurnal Penelitian dan Pengabdian kepada Masyarakat, 131-138.

Chaeruman, U. A. (2019). Mengintegrasikan Teknologi Informasi Dan Komunikasi (Tik) Ke Dalam Proses Pembelajaran: Apa, Mengapa Dan Bagaimana? Jurnal Teknodik, 046. Https://Doi.Org/10.32550/Teknodik. V0i0.536

Deda, Y. N. (2019). Workshop Media Animasi untuk Meningkatkan Kreativitas Guru di Kelurahan Kefamenanu Tengah. ETHOS: Jurnal Penelitian dan Pengabdian kepada Masyarakat, 7(1), 70-76.

Fajar, M. Y., Rohaeni, O., Permanasari, Y., Iswani, A., \& Mulkiya, K. (2017). Meningkatkan Kompetensi Guru SMA dan Sederajat Melalui Pelatihan Pembelajaran Berbasis TIK. ETHOS: Jurnal Penelitian dan Pengabdian kepada Masyarakat, 5(2), 175-181

Irmade, O., \& Widjanarko, P. (2019). Pelatihan Pembuatan Media Pembelajaran Berbasis Ict (Information Communication Technologi) Di Tk Rumah Pelangi Colomadu Karanganyar. 6.

Muslih, M. (2016). Pemanfaatan Media Pembelajaran Berbasis ICT Pada Lembaga Pendidikan Non-Formal TPQ. Dimas: Jurnal Pemikiran
Agama Untuk Pemberdayaan, 16(2), 215.

Https://Doi.Org/10.21580/Dms.2016 .162 .1090

Peraturan Pemerintah Republik Indonesia Nomor 19 Tahun 2005. (2005). Presiden Republik Indonesia.

Rivalina, R. (2014). Kompetensi Teknologi Informasi Dan Komunikasi Guru Dalam Peningkatan Kualitas Pembelajaran. 18, 12.

Rosy, B., Ranu, M. E., Nugraha, J., \& Handini, H. T. (2018). Pelatihan Media Pembelajaran Berbasis ELearning, Schoology Bagi Guru Smk Program Keahlian Administrasi Perkantoran Di Kabupaten Jombang Jawa Timur. Https://Doi.Org/10.21009/JPMM.00 2.2.02

Sari, I. P., Sari, M. N., \& Miftah, Z. (2019). Pelatihan Membuat Media Pembelajaran Interaktif Berbasis Teknologi Informas. 02.

Somantri, O., Abidin, T., Wibowo, D. S., \& Wiyono, S. (2017). Peningkatan Kemampuan Guru Dalam Membuat E-Learning Sebagai Media Pembelajaran Berbasis Teknologi Informasi Di Sma Negeri 1 Subah. 23.

Sumintono, B., Wibowo, S. A., Mislan, N., \& Tiawa, D. H. (2012). Penggunaan Teknologi Informasi Dan Komunikasi Dalam Pengajaran: Survei Pada Guru-Guru Sains Smp Di Indonesia. Jurnal Pengajaran Matematika Dan Ilmu Pengetahuan Alam, 17(1), 122. Https://Doi.Org/10.18269/Jpmipa.V $17 \mathrm{i} 1.251$

Trisisca, I., \& Sulistyo, T. (2017). Pelatihan "Pembelajaran Berbasis Ict” Bagi Guru-Guru Taman Kanak - Kanak Dan Raudhatul Athfal Kecamatan Bantur. 2(2), 5.

Undang-Undang Republik Indonesia Nomor 14 Tahun 2005 Tentang Guru 
Pelatihan Pengoperasian Media Pembelajara bagi Guru untuk Meningkatkan ... 43

Dan Dosen. (2005). Presiden

Republik Indonesia. 